\title{
ESSAY
}

\section{THE NEW LOGIC OF AFFIRMATIVE ACTION}

\author{
Charles W. Collier $\dagger$
}

Is affirmative action inherently preferential, discriminatory, and thus inconsistent with the Constitution's guarantee of equal protection? This question is basic to the legal discussion of affirmative action, and yet it seems to me that it has not been adequately addressed, much less analyzed. Clearly, there is no shortage of individual abuses and misuses in the name of "affirmative action," and these have been ainply documented elsewhere. ${ }^{1} \mathrm{My}$ primary concern is with what might be termed the "logic" of affirmative action.

This task may seem somewhat quixotic in the face of a widespread but unexamined assumption by affirmative action's critics that it is-and by its supporters that it is not-intrinsically and inevitably preferential or discriminatory. But I proceed on the highest authority. The Supreme Court has recently declared that

any person, of whatever race, has the right to demand that any governmental actor subject to the Constitution justify any racial classification subjecting that person to unequal treatment under the strictest judicial scrutiny.... [T] he Fifth and Fourteenth Amendments to the Constitution protect persons, not groups ... to ensure that the personal right to equal protection of the laws has not been infringed. These ideas have long been central to this Court's understanding of equal protection, and holding "benign" state and federal racial classifications to different standards does not square with them. ${ }^{2}$

$\dagger$ Professor of Law and Philosophy, University of Florida; Alexander von Humboldt Research Fellow, University of Frankfurt.

I thank Jeff Harrison and Mark Tushnet for helpful comments, suggestions, and criticisms.

1. See, e.g., Stephen L. Carter, Reflections of an Affirmative action Baby (1991); GlenN C. LOURY, ONE BY ONE From THE INSIDE OUT (1995); THOMAS Sowell, Preferential Policies: AN International Perspective (1990); Shelby Steele, The Content of Our Character (1990); Randall L. Kennedy, Racial Critiques of Legal Academia, 102 HARv. L. REv. 1745 (1989).

2. Adarand Constructors, Inc. v. Pena, 115 S. Ct. 2097, 2111-13 (1995). 
And President Clinton lias subsequently qualified his ringing endorsement of affirmative action with the pledge that

[affirmative action] does not mean, and I don't favor, the unjustified preference of the unqualified over the qualified of any race or gender. It doesn't mean-and I don't favor-numerical quotas. It doesn't mean, and I don't favor, rejection or selection of any employee or student solely on the basis of race or gender without regard to merit. ${ }^{3}$

I begin by considering a few working definitions of affirmative action, then proceed to analyze some of their broader implications. In the course of the discussion, I make use of social psychology and value theory to explain why adherence to a nonpreferential, nondiscriminatory model of affirmative action is so difficult.

\section{WORKING DEFINITIONS}

Definition 1. Among qualified candidates (applicants, etc.), affirmative action means that the underrepresented candidate(s) should get the nod.

Among the observations that might be made of this definition, one is that it does not explicitly try to avoid being "preferential" at all. A fair number of practices loosely labeled "affirmative action" probably proceed under some such definition. And it is not clear that this is improper, at least given certain assumptions. The first assumption is that "qualifications" may be viewed as an all-ornone classification rather than a matter of degree. That assumption miglit be unobjectionable in certain occupational fields in whicls qualifications are either very specific or merely very low. In this sense, one is either a "qualified" street sweeper or not, and it (impliedly) makes no sense to speak of a "better" or "worse" street sweeper. (Socrates spoke in this fashion when suggesting that a bad street sweeper is not "really" a street sweeper at all but rather a poor imitation of one.) The second assumption is that all qualified street sweepers are more or less interchangeable-which may also be arguable.

3. Todd S. Purdum, President Shows Fervent Support for Goals of Affirmative Action, N.Y. TIMES, July 20, 1995, at A1, B10. 
Be that as it may, one does not have to depart far from the level of lowly qualifications to find this first definition of affirmative action unrealistic and therefore unsatisfactory. President Clinton states that "[affirmative action] does not mean . . . the unjustified preference of the unqualified over the qualified of any race or gender." ${ }^{4}$ But rarely is one faced with the choice between an unqualified and a qualified candidate. The real choice is between candidates of better or worse (or simply different) qualifications. And this brings us to a second working definition:

Definition 2. Among equally qualified candidates, affirmative action means that the underrepresented candidate should get the nod..$^{5}$

Sometimes this notion is expressed in the form: "All things being equal ...." And if they were, affirmative action miglt be viewed as a relatively unproblematic "tie breaker." But when was the last time that all thimgs really were equal? Since our inquiry is logical and definitional, we must pursue this question seriously. Let us imagine two candidates for a law school teaching position, John and Jane, who attended the same elementary, junior high, and ligh school, and graduated with the same grade point average. John played first clarinet in the ligh scliool orchestra and Jane played first flute; they were co-captains of the chess team, and they drew every game between them. At Amherst, Joln showed more interest in biochemistry, and Jane took a decided liking to Renaissance art, but it was probably a wash since they attended all the same classes and graduated with the exact same grade point average. At Stanford Law School, John and Jane were moot court team partners, received identical grades in all the same courses, and ended up in a photo-finish tie in the annual greased watermelon-rolling contest. Does affirmative action mean that Jane should get the nod?

Interviewers were puzzled by their virtually identical "qualifications" but nonetheless noted some subtle, almost intangible differences of nuance. John seemed to shine more when discussing

4. Id.

5. See, e.g., Calvin O. Butts III \& Douglas E. Krantz, Lawsuits Don't Tell Affirmative Action Story; Mirror of Diversity, N.Y. TimES, Apr. 4, 1995, at A24 ("Affirmative action means that when there are two equally qualified candidates for admission to a university, for a promotion in a job or for a bank loan, then the equally qualified candidate from the minority group receives the promotion, the admission or the loan."). 
the intricacies of muddled tax opinions; Jane seemed to want to rewrite them from a policy perspective. And so forth. In other words, all things are never equal. And not only that: All things are never even remotely close to being equal, even in the most narrowly defined context possible and even for the most limited purposes imaginable. To pursue the matter in this direction is to pursue a "legal fiction" of the first order. Unless affirmative action really is inherently preferential, it cannot make use of this spurious construct of equality.

Faced with imponderables like these, the debate over logical definitions of affirmative action takes perforce a more realistic turn, as exemplified by a third working definition:

Definition 3. Among unequally qualified candidates, affirmative action means that underrepresented status serves as a "plus factor" that may elevate an (otherwise) less qualified candidate over (otherwise) more qualified candidates. (This appears to be the definition favored by former Supreme Court Justice Lewis F. Powell, Jr. $)^{6}$

This definition may be regarded as a more refined (and less naive) version of the first definition; it likewise does not explicitly try to avoid being "preferential." Alternatively, this definition may be interpreted as makmg underrepresented status itself into a substantive qualification or "credential," so that the problem of unfair preference or discrimmation is not directly presented.

Nevertheless, this definition comes hedged with a number of seemingly stringent conditions:

3(a). The guarantee of equal protection cannot mean one thing when applied to one individual and something else when applied to a person of another color. If both are not accorded the same protection, then it is not equal. ${ }^{7}$

3(b). It is far too late to argue that the guarantee of equal protection to all persons permits the recognition of special wards entitled to a degree of protection greater than that accorded others.... [T]he difficulties entailed in varying the level of judicial review according to a perceived "preferred" status of a particular racial or ethnic minority are intractable. ${ }^{8}$

6. See Regents of the Univ. of Cal. v. Bakke, 438 U.S. 265, 317-18 (1978).

7. Id. at 289-90.

8. Id. at 295. 
3(c). Preferring members of any one group for no reason other than race or ethnic origin is discrimination for its own sake. This the Constitution forbids. ${ }^{9}$

3(d). We have never approved a classification that aids persons perceived as meinbers of relatively victimized groups at the expense of other innocent individuals in the absence of judicial, legislative, or administrative findings of constitutional or statutory violations. ... Without such findings of constitutional or statutory violations, it cannot be said that the government has any greater interest in helping one individual than in refraining from harming another. ${ }^{10}$

3(e). Hence, the purpose of helping certain groups ... perceived as victims of "societal discrimination" does not justify a classification that imposes disadvantages upon persons . . . who bear no responsibility for whatever harm the [victims] are thought to have suffered. ${ }^{11}$

In the following sections, I explain why these conditions are so difficult, if not impossible, to meet. In doing so, I also draw attention to the advantages of a final definition that largely avoids these difficulties:

Definition 4. Affirmative action means equality of opportunity as opposed to equahty of outcome.

This definition has an impressive legal pedigree, going back to the concern in Carolene Products with the structure of politics, and ranging forward to John Hart Ely's notion of "policing the process of representation." Affirmative action in this sense may be defined as policing the process of selection: not in order to determine or even influence the outcome of that process (on the analogy to determining the outcome of an election), but simply to ensure that the process of selection is rigorously fair.

In what follows, I shall be concerned primarily with this "process-based" version of affirmative action. This version appears to hold the greatest promise of meeting the higher standard set out by the President and the Supreme Court.
9. Id. at 307 .
10. Id. at $307-09$.
11. Id. at 310 . 


\section{EOUAL OPPORTUNITY IN A ZERO-SUM WORLD}

A few examples will help clarify the difference between equality of outcome and process-based equality of opportunity.

Example 1. Mary, a kindergarten school teacher, decides one day to dispense lollipops to some of her favorite pupils. It happens that they are all white boys, but this does not deter her because that is not why they were chosen (she insists). This is merely her special new way of recognizing those pupils who have been especially pleasing to her.

We can imagine the following dialogue ensuing:

Mary: "Now class, as you know, I have given lollipops to some of you who have been especially pleasing to me."

Pupil (not chosen): "But teacher, isn't this awfully preferential and discriminatory, even racist and sexist?"

Mary: "Not necessarily. Such factors didn't even figure in my decision." feel?"

Pupil: "Well, how do you think it makes the rest of us

Mary: "It seems to me you shouldn't feel any different than usual. You were never given lollipops in kindergarten, and never had any reason to expect any. Lollipops are completely optional and discretionary, not a normal part of kindergarten. Objectively, nothing has happened to you at all. You should feel just fine."

Pupil: "But how can we? We feel just horrible watching your chosen few sucking on their delicious lollipops! We feel that we have been terribly and unfairly penalized!"

Mary: "I'm sorry if you feel that way but, if you do, it is because (as the Supreme Court once wisely put it) you 'choose[] to put that construction upon it. " "12

Mary's protestations notwithstanding, what clearly emerges here is that one's status may be devalued indirectly-i.e., in relation to that of others-without any overt disfavoring or direct discrimination "against" anyone.

Example 1 (continued). The next day, in response to rising resentment among her pupils and an increasingly uneasy administration, Mary organizes a random drawing to distribute additional lollipops to her pupils. Before the drawing, all the pupils

12. Plessy v. Ferguson, 163 U.S. 537, 551 (1896). 
agree that the selection procedure is random. Nevertheless, only a few more pupils receive lollipops under the new procedure.

Mary: "Well, are you satisfied now?"

Pupil (still not chosen): "I suppose it is better to suffer for no reason at all than for a bad reason, but in any case we still feel just as bad and we think it's just as unfair that we should have to suffer."

Mary: "Unfair? You all agreed beforehand that the selection procedure was random. Would you feel better if no one got lollipops or if I took away the lollipops I've already given to your lucky classmates? The technical term for that is Schadenfreude ('the perverse pleasure at the misfortune of another'), which we'll study later."

Mary's more or less unconvincing explanation illustrates the difficulty-perhaps the impossibility - of assessing one's situation in isolation. There is always a "baseline" of reasonable expectations from which departures, for better or worse, are measured, and these expectations are formed largely in terms of one's relevant peer group. ${ }^{13}$ Value is in this sense relational-even without an explicit element of competition, but especially when one is introduced:

Example 2. Martin, a concerned law professor, is concerned about evidence that women do worse in law school than men. ${ }^{14}$ He announces to his class: "From now on, women will be given ten extra points on exams. This will not affect the men, who will continue to be graded exactly as before."

While no one has seriously proposed anything quite like this as a form of affirmative action, the example illustrates an exphcitly relational value system. And of course, Martm's assurances to the men are absurd. The men are all "affected"-indeed harmed-by this elevation of their competition, even if Martin assigns them exactly the same grades they would have received anyway. Their grades have all been devalued-even if they do not realize it, even if they do not complain about it, even if they do not care. Their place in the grading "system" has changed for the worse, and if

13. See generally W.G. RUNCIMAN, Relative Deprivation and SOCIAL JUSTICE (1966); 1 SAmuel A. StOuffer et Al., The AMERICAN SOldIER: AdJUSTMENT DURING ARMY LIFE (1949).

14. E.g., Lani Guinier et al., Becoming Gentlemen: Women's Experiences at One Ivy League Law School, 143 U. PA. L. REV. 1 (1994). 
Martin's practice catches on, their grade point averages will soon start looking even less impressive than they now do.

Example 3. A university-let's call it "the University of Massachusetts at Boston"-has limited funds for bringing appointments candidates to campus. It decides to pay the travel costs for minority candidates only. White candidates are free to apply and to interview on campus-if they can get there. (Let's assume also that some other universities don't pay for anyone's travel expenses.) A university spokesman explains that "[g]iven our tight budgets, we felt this was fair."15

Quite apart from the public relations problem, is this preferential or discriminatory treatinent? Before answering, let's consider an analogous but even closer case suggested by Richard Delgado:

Example 4. Rodrigo, a law professor of African-American ancestry, was hired as a "special opportunity" appointment. Rodrigo recounts how he justified this to a Polish colleague who had not been eligible for such an appointment, even though his own parents emigrated to this country when he was two, were poor, and lived in a rough neighborhood: "I told him that I saw no problem with my being hired that way if the school used the special funds the president's office was making available to hire an additional professor that they otherwise would not have been able to hire." Delgado summarizes with approval: "In other words, you didn't displace anyone, not even the proverbial 'more highly qualified white." " 16

Without wishing to appear ungenerous, I think it is worth pondering how such an appointinent program would have to be analyzed at the university level ("the president's office"). Presumably, for every such appointment made, one fewer appointment of equal cost could be made on a race-neutral basis-the world of university finances is also a zero-sum world. ${ }^{17}$ Someone was in effect "displaced" on a racially discriminatory basis, even if Rodri-

15. Unequal Travel Expenses at UMass Boston, N.Y. TIMES, July 6, 1994, at B7.

16. Richard Delgado, Rodrigo's Tenth Chronicle: Merit and Affirmative Action, 83 GEO. L.J. 1711, 1713-14 (1995).

17. See, e.g., Hans Gesund, Letter to the Editor, YAle AlumNi Magazine, Summer 1995, at 10, 10-11 ("All universities suffer from 'insufficient' budgets. There is never enough money to do all the things the various constituencies of the institution demand."). For the rudiments of zero-sum theory, see R. DUNCAN LUCE \& HOWARD RAIFFA, GAMES AND DECISIONS 56-87 (1957); JOHN VON NEUMANN \& OSKAR MORGENSTERN, THEORY OF GAMES AND ECONOMIC BEHAVIOR \$§ 4.2, 5.2 (3d ed. 1980). 
go himself was not directly competing against anyone. And even Rodrigo seems to acknowledge this: "I, as an African-American, was ehigible for preferential treatment." 18 The same analysis might be extended even to such apparently benign imstitutions as racebased orientation, advising, tutoring, and scholarship programs.

In the search for a nonpreferential, nondiscriminatory model for affirmative action we are once again driven, it seenus, to an essentially "procedural" model, as illustrated by the final example:

Example 5. A fishing crew is charged with the mission of bringing in the best fish -of whatever variety-that it can catch. It appears from an investigation that the habitats of certain types of fish are being systematically overlooked, primarily because of certain long-standing but scientifically unsubstantiated superstitions of the crew. The new captain decrees that, henceforth, every effort will be made to ensure that these previously neglected fish are sought out with a vigor roughly approximating their known incidence.

This model is procedural in assuming that the criteria of a "good" fish are not species-dependent and can be agreed upon mdependently. ${ }^{19}$ The example also illustrates the notion of "rational expectations," both $\mathrm{n} 1$ its rejection of irrational selection criteria and in tailoring efforts to their probable yield. Rational expectations refer to the prospect of receiving what one seeks, as discounted by the mathematical probability of receiving it. ${ }^{20}$ (In a typical state lottery, for example, one has a "rational expectation" of receiving about fifty cents in return for every dollar wagered, even though no one ever actually receives this amount.) In the fishing exaniple, it would be irrationally preferential and discriminatory to expend efforts searching for fish in any habitat beyond what those efforts could rationally be expected to yield. This is so because every effort niade to find one type of fish means less time and effort available for finding other fish.

18. Delgado, supra note 16 , at 1713 .

19. See JOHN RAwLS, A THEORY OF JUSTICE $§ 14$ (1971).

20. See, e.g., 1 William Feller, AN INTRODUCTION to Probability TheORY aND ITs APplications 220-23 (3d ed. 1968); IAN HACKING, THE EMERgENCE of ProbabiliTY: A PHILOSOPHICAL STUdY OF EARLY IDEAS ABOUT PROBabiltTy, INDUCTION AND STATISTICAL INFERENCE 92-101 (1975). See generally JoN ElSTER, UlysSES AND THE SIRENS: STUDIES IN RATIONALITY AND IRRATIONALITY (rev. ed. 1984); JUDGMENT UNDER UNCERTAINTY: HeURISTICS \& BIASES (Daniel Kahneman et al. eds., 1982). 
I shall analyze the implications of this model for affirmative action in the following section.

\section{Casting a Wider Net}

In a long and thoughtful article entitled What Happened to the Case for Affirmative Action?, Nicholas Lemann articulates what he terms a "core principle" of affirmative action:

It's healthy to have some way of pushing people, as they make hiring and contracting and admissions decisions, to go far enough past the bounds of their ordinary realm of contacts to find black candidates. Even the opponents say they want this, but it won't happen if it's not required because the black-white social gulf is so great. ${ }^{21}$

The metaphor of "casting a wider net" responds to the virtually universal social dynamics of insularity captured in such phenomena as favoritism and nepotism, in-groups and out-groups, and the general hostility to anything foreign or ahen. ${ }^{22}$ These phenomena fall naturally on a continuum, ranging from inere ignorance and unfamiliarity to distrust and suspicion to outright hatred and aversion. Our term outlandish, for example, starts out meaning (literally) "of or belonging to a foreign country"; it then takes on cormotations of "unfamiliar or strange" and "hence . . odd, bizarre, uncouth," as the Oxford English Dictionary puts it. What originally meant merely "far removed from civilization" is used "now usually in a derogatory sense."23

The metaphor of casting a wider net governs the entire range of prejudice-based phenomena. To the extent that the problem is nierely one of neutral unfamiliarity or ignorance, the metaphor provides a rational corrective in the form of more inclusive methodologies. To the extent that the problem is one of overt hostility

21. N.Y. Times Magazine, June 11, 1995, at 36, 62.

22. See, e.g., T.W. Adorno ET AL, THE AUthortTarian PERSONALITY (1950); Gordon W. Allport, The NATURE of Prejudice (1954); NoRbert Elias \& JoHN L. SCOTSON, THE ESTABLISHED AND THE OUTSIDERS: A SOCIOLOGICAL INQUIRY INTO COMMUNITY PROBLEMS (2d ed. 1994); ROBERT S. LYND \& HELEN MERRELl LYND, MIDDLETOWN: A STUDY IN CONTEMPORARY AMERICAN CULTURE (1929); GUNNAR Myrdal, AN AMERican DILEMma: THE Negro PROBLEM AND MODERn DEMOCRACY (1944); Robert K. Merton, Insiders and Outsiders: A Chapter in the Sociology of Knowledge, 78 AM. J. Soc. 9 (1972).

23. OXFORD ENGLISH DICTIONARY 1021 (2d ed. 1989). 
and aversion, it places procedural obstacles in the way of irrational limitations on the field of inquiry.

The social psychology of insularity is well recognized in American legal doctrine. In the context of pondering stricter scrutiny of "legislation which restricts those political processes [such as voting, expression, and political association] which can ordinarily be expected to bring about repeal of undesirable legislation," the Carolene Products Court faniously pondered

whether similar considerations enter into the review of statutes directed at particular religious ... or national ... or racial minorities ... whether prejudice against discrete and insular minorities may be a special condition, which tends seriously to curtail the operation of those political processes ordinarily to be relied upon to protect minorities, and which may call for a correspondingly more searching judicial inquiry. ${ }^{24}$

In the present context, discreteness, insularity, and prejudice tend to set irrational (and perhaps unconscious) limits on the methodology of selection; affirmative action may be viewed as a form of "strict scrutiny" to ensure that selection procedures conform to rational expectations based on all available information. To return to the fishing analogy, it would be irrational to confine one's efforts to certain familiar habitats in the face of credible evidence that other equally good habitats were being systematically neglected.

The criteria for evaluating the results of a procedural theory are themselves necessarily procedural; or, as Ely has put it, "[I]f a theory is sound, we should live with the results." ${ }^{\prime 25}$ No one would dreain of contesting the results of an election on the ground that the "preferred" candidate lost. Similarly, while a criminal conviction is invalid when meinbers of the defendant's race are excluded by law froin jury duty, the same conviction arrived at by the sanie jury chosen under fair and race-neutral jury selection procedures would be upheld. ${ }^{26}$ So too witlı affirmative action: "Results" can-

24. United States v. Carolene Prod. Co., 304 U.S. 144, 152-53 n.4 (1938) (citations omitted).

25. JoHn HART Ely, Democracy AND Distrust 152 (1980).

26. See Taylor v. Louisiana, 419 U.S. 522, 538 (1975) ("[I]n holding that petit juries must be drawn from a source fairly representative of the community we impose no requirement that petit juries actually chosen must mirror the commnnity and reflect the various distinctive groups in the population. Defendants are not entitled to a jury of any 
not be relevant as a criterion of procedure; they neither confirm nor disprove that affirmative action procedures are being conducted in a nonpreferential, nondiscriminatory manner. At most, outcomes that are wildly at variance with rational expectations suggest the need for more up-to-date empirical mformation to revise and inform expectations; they do not suggest that those procedures should conform to something other than informed, rational expectations.

This is a difficult implication of my discussion, and it runs up against common imtuitions. Here, for example, is how a typical law school's faculty appointments committee was instructed by its dean:

I ask the committee to continue the College's commitment to the hiring of women and minority law teachers. This must be a matter of very high priority in order for us to be successful. ${ }^{27}$

It is not at all clear that this commitment could be met in a nonpreferential, nondiscriminatory manner. Nor is it clear what "successful" means in this context. Could a procedurally fair selection procedure that conformed to rational expectations be prononnced "successful" even if it nevertheless yielded no women or minority law teachers? If not, then some notion of equality or proportionality of outcomes or results is implicitly being substituted for equality of opportunity as described above.

Anotlier distortion of affirmative action may be described as "overcorrection," and it too derives strength fron common intuitions. This phenomenon may perhaps best be illustrated by juxtaposing the nondiscrimination standard of the Association of Anterican Law Schools, as published in its Placement Bulletin, with the affirmative action statenient in a typical job advertisement in that same bulletin:

Unless otherwise expressly stated, all institutions announcing positions herein have adopted and pursue policies not to discriminate on the ground of race, color, national origin, sex, age, handicap or disability, or sexual orientation ....

particular composition . . . .); Carter v. Jury Comm'n, 396 U.S. 320, 343 (1970) (Douglas, J., dissenting in part); Swain v. Ala., 380 U.S. 202, 208-09 (1965); Strauder v. W. Va., 100 U.S. 303 (1879).

27. Memorandum on file with the author. 
UC Davis has a strong institutional coinmitment to diversity among its faculty and staff. In that spirit, we are particularly interested in receiving applications from persons of underrepresented groups, including women, persons of color, special disabled veterans, Vietnam era veterans, and persons with disabilities. $^{28}$

It would be a rare individual indeed who could coinbine these two inandates in a nonpreferential, nondiscriminatory manner. (It goes without saying that the UC Davis Law School is "not particularly interested in receiving apphications froin white males.") Those things that are most highly sought out are commonly and naturally assuined to be the inost valuable. In fact, it is precisely because they are most highly sought out that they are most valuable. If diamonds suddenly became as common as pebbles, their value would pluminet accordingly; it is their relative scarcity-and the greater labor expended in finding thein-that accounts for their high value..$^{29}$ It would thus be highly counterintuitive to expect that someone, after being instructed to place the highest priority on searching for soinething, could then step back and inaintain a kind of detached neutrality as to the results of that search. ${ }^{30}$ But this is precisely the sort of "cognitive dissonance" affirmative action entails. The fishing analogy, for example, might play out as follows:

First Mate: "Well, lads, you've heard the captain's new orders. We've been neglecting certain varieties of perfectly good fish, and that won't do. In the future, you will seek out those previously neglected fish 'with a vigor approximating their known incidence." "

Second Mate: "Sir, what does that mean in practice? Are we supposed to make extra special efforts to find those underrepresented fish?"

First Mate: "I'm asking the entire crew to support the captain's coinmitment to finding and catching those previously

28. AAls Placement Bulletin 1, 2 (Oct. 7, 1994).

29. See Haslem v. Lockwood, 37 Conn. 500, 506 (1871) (finding that, in gathering up a quantity of horse manure, plaintiff had "changed its original condition and greatly enhanced its value by his labor"); JOHN LOCKE, Second Treatise of Government in Two Treatises of Government, 285, 303-20 (2d ed. Canbridge Univ. Press 1967) (1690); 1 Karl MarX, Capital 8-9 (Ernest Rhys ed. \& Eden \& Cedar Paul trans., J.M. Deut \& Sons Ltd. Books 1930) (1867).

30. See Leon festinger, A Theory of Cognitive Dissonance 1-31 (1957). 
neglected fish. This must be a matter of very high priority in order for us to be successful. So, do whatever it takes, but don't go overboard (if you know what I mean)."

Second Mate: "Does this mean we are changing our criteria for a good fish? Or are the new fish actually better?"

First Mate: "Why do you think we are looking so hard for them?! All I know is that the captain would be mighty pleased to see you bring in some of those new fish!"

In this example, as in the real world, what started out as a selection methodology guided by rational expectations as to what it can yield has been obscured and distorted in perfectly understandable ways by the workings of social psychology. The "First Mate" is patterned on the bureaucratic intermediary who converts a procedural mandate into the hard currency of outcomes, which can then most easily be achieved by "overcorrecting" in preferential or discriminatory fashion.

In the real world, this plays out as follows:

To its credit, the Appointments Committee did look primarily at minority candidates. In my view, this is no more unusual than the fact that in some years the Committee looks primarily for torts teachers or clinicians, depending on the needs of the institution. $^{31}$

In other words, minority status has been translated into a "credential" like expertise in torts. ${ }^{32}$ If this were accepted, then the issue of preference or discrimination would have been finessed since everyone agrees it is permissible-indeed, obligatory-to discriminate on the basis of legitimate credentials. But what this really represents is the institutionalization of preference and discrimination, so that preferential and discriminatory decisionmaking eventually begins to seem "no more imusual" than the fact that earned credentials are considered.

This imstitutionalization of preference and discrimination is often justified in the name of enhancing diversity, which should lead $\mathrm{m}$ turn to the breakdown of common stereotypes. But the suggestion that unearned, immutable physical characteristics can serve as a proxy for intellectual ability or as a substitute for accomplishment may be the unkindest stereotype of all. ${ }^{33}$ (And

31. Memorandum on file with the author.

32. See Kennedy, supra note 1, at 1801-07.

33. See Hishon v. King \& Spalding, 467 U.S. 69, 81 (1984) (Powell, J., concurring) 
even when it is accurate, the Supreme Court has ruled that such a stereotype may not be acted on. ${ }^{34}$ )

The nondiscrimmation principle was originally premised on the notion that, in order to extend the sphere of freedom, an enlightened society should abstract as far as practicable from immutable natural differences and physical limitations. ${ }^{35}$ More generally, the gradual transcending of natural differences is one of the broadest trends observable in the advance of civilization and one of those "evolving standards of decency that mark the progress of a maturing society." ${ }^{36}$ It would represent a most unfortunate reversal of those beneficent and civilizing trends if "biology is destiny" once again became the inspiration for stereotyping and discrimination based on immutable natural differences-even those viewed as "credentials."

\section{THE PRoblem of INFormal Discrimination}

Formal discrimination, it may be said, ended in America with the passage of the Civil Rights Act of $1964 .{ }^{37}$ But of course all discrimination did not promptly end once it had been made formally illegal; "informal discrimination" of the sort found in attitudes, unconscious predispositions, and the reinforcement of society's cultural stereotypes continues to be a problem that has been documented by critical race scholars. ${ }^{38}$

("The qualities of mind, capacity to reason logically, ability to work under pressure, leadership, and the like are unrelated to race or sex."); Roberts v. United States Jaycees, 468 U.S. 609, 627-28 (1984) (declining to indulge in such "stereotyping"); see also City of Cleburne v. Cleburne Living Ctr., 473 U.S. 432, 455 (1985) (Marshall, J., concurring in part and dissenting in part); United States v. Kras, 409 U.S. 434, 458-60 (1973) (Marslall, J., dissenting).

34. See City of Los Angeles Dep't of Water \& Power v. Manhart, 435 U.S. 702, 708 (1978) ("Even a true generalization about the class is an insufficient reason for disqualifying an individual to whom the generalization does not apply."); see also Craig v. Boren, 429 U.S. 190, 201-04 (1976) ("Even were this statistical evidence accepted as accurate, it nevertheless offers only a weak answer to the equal protection question presented Itere. . . . [P]roving broad sociological propositions by statistics is a dubious business, and one that inevitably is in tension with the normative philosophy that underlies the Equal Protection Clause."); $c f$. id. at 202 n.13 (discussing similar cases).

35. See, e.g., Strauder v. West Virginia, 100 U.S. 303, 308 (1879); Paul Brest, Foreword: In Defense of the Antidiscrimination Principle, 90 HARV. L. REV. 1, 8-9 (1976).

36. Trop v. Dulles, 356 U.S. 86, 101 (1958). See generally James Harvey Robinson, Civilization \& Culture, in ENCYClopaedIA BRITANNICA 824 (14til ed. 1973).

37. Pub. L. No. 88-352, 78 Stat. 241 (1964) (barring discrimination in Iiring, education, ltousing, etc.).

38. See, e.g., Richard Delgado \& David Yun, The Neoconservative Case Against Hate- 
Future historians will probably view the years 1995-96 as the period when the preferential and discriminatory practices of affirmative action began to end. ${ }^{39}$ But what will not have ended is an exact correlate to the informal discrimination identified by the critical race scholars. Likewise, and for the foreseeable future, the informal discrimination associated with affirmative action will have to be reckoned with.

This is not a minor or marginal problem. In the academy, at least, it must be counted as an absolutely central concern. Three factors conspire to make it so: (1) the relatively high level of qualifications at issue; (2) the relatively small number of individuals concerned; and (3) the widespread support for affirmative action in academia, at least among those not affected by it.

The issue of affirmative action in academia is often understood in terms of mclusion or inclusiveness. Thus, a university president has stated:

Especially in a university, [affirmative action is] about creating the best educational atmosphere for all students. ${ }^{40}$

Similarly, a law professor has declared:

[A]ffirmative action ... doesn't just benefit minorities, it benefits all students. .. Bakke-like affirmative action on the Harvard model brings us together. ${ }^{41}$

To view affirmative action in this way is to view it as presenting solely issues of educational policy and to abstract entirely from

Speech Regulation-Lively, D'Souza, Gates, Carter, and the Toughlove Crowd, 47 VAND. L. REv. 1807 (1994); Linda Hamilton Krieger, The Content of Our Categories: A Cognitive Bias Approach to Discrimination and Equal Employment Opportunity, 47 STAN. L. Rev. 1161 (1995); Charles R. Lawrence III, The Id, the Ego, and Equal Protection: Reckoning with Unconscious Racism, 39 STAN. L. REv. 317 (1987); Thomas F. Pettigrew, New Patterns of Racism: The Different Worlds of 1984 and 1964, 37 RUTGERS L. REV. 673 (1985); Michael Selmi, Testing for Equality: Merit, Efficiency, and the Affirmative Action Debate, 42 UCLA L. REV. 1251, 1283-89 (1995) (reviewing literature).

39. See, e.g., Adarand Constructors, Inc. v. Pena, 115 S. Ct. 2097 (1995); Equal Opportunity Act of 1995, H.R. 2128, 104th Cong., 1st Sess. (1995); B. Drummond Ayres Jr., California Board Ends Preferences in College System, N.Y. TiMES, July 21, 1995, at A1; see also B. Drummond Ayres Jr., California Acting on Affirmative Action, N.Y. TMmES, Mar. 26, 1995, at A1 (discussing Califomia Civil Rights Initiative).

40. Peter Applebone, The Debate on Diversity in California Shifis, N.Y. TIMES, June 4, 1995, at A1, A22. (quoting Chang-Lin Tien, Chancellor of the University of California at Berkeley).

41. Akhil Amar \& Neal Katyal, School Colors, NEw REPuBlic, July 17 \& 24, 1995, at 25 . 
any legal or constitutional rights involved. The above statements should therefore be corrected:

Especially in a university, [affirmative action is] about creating the best educational atmosphere for those students who are admitted to the university.

[A]ffirmative action ... doesn't just benefit minorities, it benefits all students who are admitted for study. . . Bakke-like affirmative action on the Harvard model brings those of us together who are privileged to be here.

Only thus is the full issue presented for consideration.

To return to an earlier example: If large numbers of people are applying to be street sweepers, and if (as I shall assume for simplicity) the qualifications for such a job are fairly minimal, then something would probably be seriously amiss if applicants were not accepted in rough proportion to their race, sex, religion, etc. The fact that there is not much of a "selection procedure" to speak of here warrants a more outcome-oriented approach for assessing the fairness of the selection. The "law of large numbers" dictates that variations froin expected frequencies should diminish and virtually disappear when sufficiently large samples are generated on an essentially random basis. ${ }^{42}$

Situation 1. The city of New Angeles, one of the nation's largest employers, hires about 1,000 street sweepers per year from an applicant base of about 10,000 . Where job qualifications are either very specific or merely very low, the employment office is authorized to make hiring decisions randomly-from among the "qualified" applicants-by means of a special, computerized selection program; and most hiring decisions as to street sweepers are in fact made this way. ${ }^{43}$

However, these conditions are rarely, if ever, approximated in academia, and something would be seriously amiss if they were. The academic situation is more like the following:

Situation 2. Ivy Law School, one of the nation's leading institutions, appoints about three new professors per year from an

42. See, e.g., FELLER, supra note 20, at 152-53, 202-04, 243-63; HACKING, supra note 20 , at $154-65$.

43. For the general idea, see Jon ElSTER, SOlOMONIC JUdGEMENTS: STUdIES IN THE LiMITATIONS OF RATIONALITY 36-122 (1989). 
applicant pool of about 1,000. In appointments matters, the Ivy faculty has long had something of a bias in favor of its own graduates (which it justifies on the ground that it is, after all, one of the nation's leading institutions). The faculty follows an informal practice of trying to appoint at least one of its own graduates every year. As a result, almost half of Ivy's faculty members are Ivy graduates.

This situation is governed by what might be termed the "law of small numbers" because decisions of this sort are made on a highly imdividualized, discretionary basis; here, something would probably be seriously amiss if the results did conform closely to statistical expectations. In fact, however, Ivy's own graduates are grossly overrepresented on its faculty as a result of the slight preference in their favor. If questioned, Ivy faculty members would doubtless concede that their graduates are not inherently superior to those of other leading institutions; however, those same faculty members would probably see nothing wrong about giving a slight preference to an Ivy graduate in a close case. This example, which is not entirely hypothetical, illustrates the huge effects of informal discrimination based on some factor other than merit in a situation in which every case is "close." If every institution followed Ivy's practice, the appointments process in general would have little mtegrity.

Now consider the situation at a typical law school, as reported by its appointments committee chairman:

First, the background. As you know, what has evolved in the Committee's deliberations is a "white" standard and a "black" standard as far as traditional bases for law school hiring. It is pretty much this simple since white women, in my opinion, are now held to the same standards as white men. If you have any doubts about this, please feel free to view all the candidates we interviewed in the context of all 1250 AALS sheets. . .

In my view the overriding rule in the Committee this year was "no white men." Another outcome, and I am not sure how this evolved, was "almost no white women." I observed the first rule religiously but not the second. We did attempt to interview one white male-Editor in Chief of the Yale Law Journal-but he canceled.

My recollection is that, with a possible exception or two, we did not interview a single black candidate who would have been interviewed had he or she been white ... if we were considering white candidates in the first place. 
.. Probably all of us on the Committee struggled with this, although we did not talk about it openly. ${ }^{44}$

Turn the clock back, reverse the races, and we have a picture eerily reminiscent of the segregation era in this country. ${ }^{45}$ While this case is perhaps an extreme one, it falls squarely within the famihar pattern of informal discrimination outlined above. The discrimination at issue here is unwritten, unspoken, and undecidedupon; it is the kind that lies in "attitudes, unconscious predispositions, that sort of thing," 46 and as such has no formal legal status. Yet there can be no doubt that its effects are just as decisive and pernicious as if the committee had publicly debated and officially adopted the informal "rules" summarized by its chairman.

If every institution followed this practice, the appointments process in general would obviously afford no equality of opportunity at all. And there is little to prevent that result in the highly individualized and discretionary context of academic decisionmaking or to suggest that such a result would be surprising. .7 "If $^{4}$ universities are free to discriminate at all to admit inembers of preferred groups, they will, as a practical matter, be able to discriminate to whatever extent is necessary to adnit the desired numbers." ${ }^{48}$ I can thus claim only to have presented the elements

44. Memorandum on file with the author.

45. See, e.g., Sweatt v. Painter, 339 U.S. 629, 636 (1950) ("[T]he Equal Protection Clause of the Fourteenth Amendment requires that petitioner be admitted to the University of Texas Law School."); Missouri ex rel. Gaines v. Canada, 305 U.S. 337, 351 (1938) ("[P]etitioner's right was a personal one. It was as an imdividual that he was entitled to the equal protection of the laws, and [to] facilities for legal education substantially equal to those which the State there afforded for persons of the white race . . . ").

46. Delgado, supra note 16 , at 1723 .

47. See Paul D. Carrington, Diversity!, 1992 UTAH L. REv. 1105, 1192-1203; Michael Stokes Paulsen, Reverse Discrimination and Law School Faculty Hiring: The Undiscovered Opinion, 71 TEX. L. REV. 993 (1993) (describing "anonymous" judicial opinion on legality of particular faculty appointments process).

48. Lino A. Gragha, Hopwood v. Texas: Racial Preferences in Higher Education Upheld and Endorsed, 45 J. LEGAL EDUC. 79, 87 (1995). For similar conclusions from across the political spectrum, see, e.g., RONALD DWORKIN, A MATTER OF PRINCIPLE 309-11 (1985); Lemann, supra note 21, at 54 ("[I]n admissions-office circles [Bakke] is widely viewed as meaning that it's O.K. to reverse discriminate as long as you're not really obvious about it."); Mark Tushnet, Justice Lewis F. Powell and the Jurisprudence of Centrism, $93 \mathrm{MICH}$. L. REV. 1854, 1875 (1995) ("[T]he Harvard program was a more genteel way of accomphishing the same results as the plan in Bakke, and ... on the margins a plus factor has precisely the same effect as that plan; Powell's position was ... "pure sophistry." "). 
of nonpreferential, nondiscriminatory analysis for a legal regime of the indefinite future.

It can no longer be maintained (at least not with a straight face) that " $[t]$ here is no compelling evidence that there is discrimination by race and gender in affirmative action." ${ }^{49}$ In a zero-sum world, for every "affirmative action" there is an equal and opposite reaction. As one prominent law dean has candidly conceded (even while defending his own institution's affirmative action program in court), "One of the plain, unvarnished and difficult truths about affirmative action is ... that there are 'innocent' victins. They are denied opportunities they would otherwise have had. There is no way of plastering over that reahty. Too often we try to unake it appear to be a bloodless decision." 50 This is evidently also what the Supreme Court had im mind in a gender discrimination case:

[S]ince sex, like race and national origin, is an immutable characteristic determined solely by the accident of birth, the imposition of special disabilities upon the members of a particular sex because of their sex would seem to violate "the basic concept of our system that legal burdens should bear some relationship to individual responsibility." ${ }^{51}$

The pervasiveness and severity of informal discrimination have finally transformed what might have been viewed as a matter of educational or public policy into a fundamental legal issue of civil rights. It is finally time to debate this legal and constitutional issue as such. And there is no longer any reason to apologize for opposing the evils of discrimination-im whatever forn they take.

49. B. Drummond Ayres Jr., Affirmative Action's End? Now It's Not That Simple, N.Y. TIMES, July 24, 1995, at A1, A10 (quoting the Rev. Jesse Jackson).

50. Ken Myers, Prospective Student's Lawsuit ls Sending U.T. Back to Bakke, NAT'L L.J., Aug. 1, 1994, at A14 (quoting Acting Dean at University of Texas Law School, M. Michael Sharlot). A faculty member on the law school's legal team was equally candid: "Are there white applicants who were not admitted who would have gotten in if they had been black? . . . The answer is clearly yes. That's the nature of a racial preference." Richard Bernstein, Racial Discrimination or Righting Past Wrongs?, N.Y. TIMES, July 13, 1994, at B8 (quoting University of Texas Law School professor Samuel Issacharoff).

51. Frontiero v. Richardson, 411 U.S. 677, 686 (1973) (citation omitted). 